\title{
Bioedusiana
}

Blölogy

http://jurnal.unsil.ac.id/index.php/bioed

Education

Department

Universitas Siliwang

DOI: https://doi.org/10.37058/bioed.v6i2.3281

\section{Penggunaan "E-Learning Madrasah" terhadap Motivasi Belajar Siswa di Masa Pandemi Covid-19 pada Pelajaran IPA}

\section{The Use of "Madrasah E-Learning" on Student Learning Motivation during the Covid-19 Pandemic in Science Lessons}

\author{
Iim Halimatul Mu'minah ${ }^{1 *}$, Muhamad Kurnia Sugandi ${ }^{2}$, Aden Arif Gaffar ${ }^{3}$ \\ 1,2,3 Program Studi Pendidikan Biologi, FKIP, Universitas Majalengka, Jln. K.H. Abdul Halim No. 103 \\ Kabupaten Majalengka, Jawa Barat 45418, Indonesia
}

\begin{abstract}
Abstrak
Pembelajaran di masa pandemi Covid-19 disarankan untuk dilaksanakan secara daring, agar dapat mengurangi dampak penyebaran virus SARS-CoV-2. Salah satu unsur pendukung yang dapat menfasilitasi pembelajaran daring adalah Learning Management System (LMS). LMS merupakan sebuah software yang didesain untuk membuat, mendistribusikan, dan mengatur penyampaian konten pembelajaran. Di antara sekian banyak LMS yang digunakan oleh guru dan siswa, khusus di lingkungan madrasah adalah "E-Learning Madrasah". Penelitian ini bertujuan untuk mengetahui efektivitas penggunaan E-Learning Madrasah terhadap motivasi belajar siswa selama masa pandemi Covid-19 pada mata pelajaran IPA. Metode penelitian yang digunakan adalah pre-eksperimen karena tanpa adanya kelas kontrol, populasi penelitian ini yaitu siswa kelas VII MTs Negeri 2 Majalengka yang dipilih menggunakan teknik purposive sampling dengan mempertimbangkan homogenitas populasi. Hasil penelitian menunjukkan nilai rata-rata pretest sebesar 77,07 dan posttest sebesar 87,7. Analisis $N$-Gain pada pembelajaran daring berbasis E-Learning madrasah menunjukkan angka sebesar 0,48 dengan kategori sedang. Keterlaksanaan penggunaan E-Learning Madrasah memiliki kriteria efektif. Efektivitas penggunaan E-Learning madrasah dinilai efektif dalam meningkatkan motivasi belajar siswa selama pandemi Covid-19 pada mata pelajaran IPA.
\end{abstract}

Kata kunci: E-Learning Madrasah; Motivasi; Pandemi Covid-19

\begin{abstract}
Learning activity during the Covid-19 pandemic is recommended to be carried out online to reduce the impact of the spread of the $S A R S-C o V-2$ virus. One of the supporting elements that can facilitate online learning is the learning management system (LMS). LMS is designed to create, distribute, and manage learning content delivery. Among the many LMS used by teachers and students, specifically in the madrasa environment, is "E-Learning Madrasah". This study aims to determine the effectiveness of using Madrasah E-Learning on students' learning motivation during the COVID-19 pandemic in science subjects. The research method used was pre-experimental because, without a control class, the population of this study was class VII students of MTs Negeri 2 Majalengka. They were selected using a purposive sampling technique by considering population homogeneity. The results showed the average value of the pretest was 77,07, and the posttest was 87,7. The N-Gain analysis on online learning based on E-Learning madrasah shows of 0.48 in the medium category. The implementation of the use of Madrasah E-Learning has effective criteria. Using madrasah E-Learning is considered effective in increasing student learning motivation during the Covid-19 pandemic in science subjects.
\end{abstract}

Keywords: E-Learning Madrasah; Motivation; Covid-19 Pandemic

Article History

Received: July 6 ${ }^{\text {th }}, 2021$; Accepted: December $30^{\text {th }}, 2021$; Published: December $31^{\text {st }}, 2021$

Corresponding Author*

Iim Halimatul Mu'minah, Program Studi Pendidikan Biologi FKIP Universitas Majalengka, iimhalimatul@unma.ac.id

(C) 2021 Bioedusiana. This is an open access article under the CC BY-SA 4.0 license (https://creativecommons.org/licenses/by-sa/4.0/) 


\section{PENDAHULUAN}

Bencana pandemi Covid-19 yang melanda dunia selama kurang lebih dua tahun ini, telah memaksa seluruh sendi kehidupan untuk "beristirahat" sementara waktu guna mencegah penyebaran virus SARS-CoV-2 (Abdelmola et al., 2021; Rahmi, 2020; Sharma \& Singh, 2017). Hal tersebut tentunya berdampak juga pada dunia Pendidikan, yang terpaksa harus menggunakan sistem pembelajaran daring atau jarak jauh agar tetap melaksanakan proses pembelajaran (Aji, 2020; Sadikin \& Hamidah, 2020; Zulkifli \& Ferdiansyah, 2021). Kebijakan tersebut tidak hanya berlaku di Indonesia namun berlaku di seluruh negeri di dunia yang sudah terpapar Covid-19. Kebijakan pembelajaran daring yang dilaksanakan oleh seluruh penyelenggara Pendidikan merupakan upaya melaksanakan physical distancing sebagai upaya pencegahan penularan Covid-19 lebih lanjut (Jogezai et al., 2021). Namun demikian, physical distancing tersebut dapat membatasi laju pertumbuhan dan perkembangan dalam berbagai bidang kehidupan, baik bidang ekonomi, sosial dan terutama bidang pendidikan.

Adanya pandemi ini telah menuntut semua orang untuk melakukan Work From Home (WFH) (Rosali, 2020; Sethi \& Behera, 2021). Kebijakan WFH tertuang dalam surat Edaran Menteri Pendayagunaan Aparatur Negeri serta Reformasi Birokrasi (Menpan RB) No 50/2020 tentang perubahan Kedua atas Surat Sistem Kerja Aparatur Sipil Negara dalam upaya melangsungkan proses pendidikan diharapkan dilakukan secara daring. Akan tetapi dalam penerapan pembelajaran secara daring pasti mempunyai sekian banyak hambatan. Salah satu hambatan terberat dalam pembelajaran daring adalah sistem jaringan internet dan perangkat lunak yang dapat mendukung proses pembelajaran tersebut (Gohiya \& Gohiya, 2020; Putria et al., 2020; Rosali, 2020).

Pembelajaran daring memanfaatkan jaringan internet dengan aksesbilitas dan konektivitas serta memerlukan suport perangkat-perangkat mobile semacam smarthphone, tablet dan laptop yang dapat digunakan untuk mengakses data dimana saja serta kapan saja (Clark et al., 2021; Hartanto, 2016; Rosali, 2020). Sadikin \& Hamidah (2020) menyatakan bahwa pemanfaatan teknologi digital memungkinkan peserta didik dan pengajar berada pada tempat yang berlainan selama proses pembelajaran berjalan. Pemanfaatan Learning Management System sebagai alternatif peserta didik memahami materi pelajaran dengan optimal. Hal ini selaras dengan sebuah hasil penelitian yang dilakukan oleh Ibrahim \& Suardiman (2014) bahwa terdapat pengaruh yang positif penggunaan E-Learning terhadap motivasi dan prestasi belajar siswa di tingkat sekolah dasar.

Seperti halnya di MTs Negeri 2 Majalengka, yang menerapkan pembelajaran daring dengan memanfaatkan Learning Management System (LMS) yang sedang diujicobakan di kalangan sekolah-sekolah yang berada di bawah naungan Kementerian Agama yakni "ELearning Madrasah", Platform digital ini dapat digunakan untuk mengunggah materi pelajaran 
dalam berbagai format, seperti pdf, Word, PowerPoint, dan video pembelajaran berbasis MP4. Penggunaan E-Learning Madrasah belum sepenuhnya efektif terutama dalam meningkatkan motivasi belajar siswa selama berada di rumah. Selain itu juga, pembelajaran daring menjadi salah satu kendala bagi guru dalam menyampaikan materi pelajaran. Berdasarkan hasil observasi dan wawancara dengan salah satu pengajar di MTs Negeri 2 Majalengka, ada berbagai jenis media pembelajaran daring yang sebelumnya telah diterapkan dalam proses pembelajaran di MTs Negeri 2 Majalengka yakni menggunakan WhatsApp group. Akan tetapi Kementerian Agama memiliki sebuah inovasi dengan mencoba mengimplementasikan media pembelajaran daring berbasis E-Learning madrasah untuk sekolah-sekolah yang berada di bawah naungan kementerian agama. Kondisi tersebut mendasari penulis untuk melakukan sebuah penelitian ini karena merasa tertarik untuk diteliti dengan tujuan untuk melihat keefektifan pembelajaran daring berbasis E-Learning madrasah dan untuk mengetahui motivasi belajar siswa pada masa pandemi Covid-19 pada mata pelajaran IPA di MTs Negeri 2 Majalengka.

Berdasarkan beberapa penelitian terdahulu yang telah dilakukan seperti penelitian serupa telah oleh Mustakim (2020) yang menggunakan media online selama pandemi Covid-19 pada mata pelajaran matematika, menyimpulkan bahwa peserta didik menilai pembelajaran matematika menggunakan media daring sangat efektif (23\%). Sebagian besar mereka menilai efektif $(46,7 \%)$ dan menilai biasa saja (20\%). Walaupun ada Sebagian peserta didik yang menganggap pembelajaran daring tidak efektif sebanyak (10\%) dan sama sekali tidak ada $(0 \%)$ yang memberikan penilaian sangat tidak efektif. Kemudian, pemanfaatan media pembelajaran daring berupa Google Form dengan judul efektivitas penggunaan Google Form dalam pembelajaran daring pada mata pelajaran pemeliharaan mesin sepeda motor di SMK Negeri 1 Koba menyatakan bahwa penggunaan Google Form sebagai media pembelajaran daring menunjukkan respon positif, ini dapat dilihat dari rata-rata persentase sebesar $72,66 \%$ dengan kategori baik (Septiawan, 2020).

Penelitian selanjutnya yang dilakukan Januarisman \& Ghufron (2016) memperoleh hasil bahwa: (1) Produk berupa media pembelajaran berbasis web pada mata pelajaran IPA menggunakan software Content Management System (CMS) Wordpress; (2) Produk media pembelajaran berbasis web pada mata pelajaran IPA telah dinyatakan layak sebagai media pembelajaran berdasarkan hasil validasi para ahli materi dengan nilai rata-rata 3,98 dengan kategori baik, ahli media dengan rata-rata 4,07 dengan kategori baik, uji lapangan awal diperoleh rata-rata penilaian sebesar 4.13 dengan kategori baik dan uji coba lapangan utama diperoleh ngain untuk SMP Muhammadiyah 2 sebesar 22,2; dan (3) Keefektifan media pembelajaran IPA berbasis web dibuktikan dengan meningkatnya hasil belajar siswa berdasarkan data hasil evaluasi pretest-posstest. 
Berdasarkan paparan penelitian-penelitian sebelumnya, kebaruan pada penelitian yang dilakukan kali ini oleh penulis adalah media pembelajaran daring yang digunakan dalam pembelajaran pada penelitian ini adalah berbasis E-Learning Madrasah, yang mana media $E$ Learning madrasah ini merupakan sebuah inovasi khusus yang diluncurkan untuk sekolahsekolah yang berada dibawah naungan kementerian agama sebagai sebuah solusi dalam pembelajaran daring. Seperti halnya pada penelitian ini dilakukan MTs Negeri 2 Majalengka yang sudah mulai mengimplementasikan media pembelajaran daring tersebut sehingga penulis ingin meneliti sejauh mana efektivitas penggunaan media pembelajaran daring berbasis $E$ Learning madrasah selama masa pandemi Covid-19 pada mata pelajaran IPA.

Efektivitas media pembelajaran daring sangat berpengaruh dalam proses pembelajaran daring selama masa pandemi Covid-19, pengaruh suatu media pembelajaran daring dapat memahamkan peserta didik dan itu menjadi salah satu tolak ukur yang sangat penting dalam pembelajaran (Nugraha et al., 2020). Media pembelajaran daring dapat dimaknai sebagai sebuah media yang dilengkapi dengan alat pengontrol yang dapat dioperasikan oleh pengguna dan tentu dapat mengendalikan dan mengakses apa yang menjadi kebutuhan pengguna, seperti mengunduh referensi-referensi terutama materi Januarisman \& Ghufron (2016). Manfaat yang didapat dari penggunaan media pembelajaran daring adalah bersifat mandiri dan interaktivitas yang tinggi, meningkatkan ingatan, memberikan banyak pengalaman belajar dengan teks, audio, video dan animasi yang semuanya dapat dimanfaatkan untuk menyampaikan informasi atau pesan dan memberikan kemudahan menyampaikan, mengunggah isi, mengunduh, peserta didik juga data mengirim email pada peserta lainnya, mengirim komentar pada forum diskusi, menggunakan fitur chat hingga link video cenference untuk dapat komunikasi langsung bertatap maya. Tujuan penelitian ini adalah untuk mengetahui efektivitas penggunaan E-Learning Madrasah terhadap motivasi belajar siswa selama masa pandemi Covid-19 pada mata pelajaran IPA.

\section{METODE}

Penelitian ini merupakan penelitian pre-eksperimen. Penelitian dilakukan di MTs Negeri 2 Majalengka Kabupaten Majalengka. Lokasi ini dipilih karena terdapat beberapa pertimbangan di antaranya permasalahan yang sesuai untuk dijadikan penelitian, tersedianya data-data yang mendukung penelitian, dan berbagai faktor penunjang lainnya yang menjadikan peneliti memilih lokasi ini. Selain itu, sekolah ini berada di bawah Kementerian Agama Republik Indonesia, yang mulai menerapkan aplikasi media pembelajaran online yang dinamakan 'E-Learning madrasah'. Populasi dan sampel dalam penelitian ini adalah siswa kelas VII MTs Negeri 2 Majalengka semester genap tahun pelajaran 2020/2021 dengan teknik pengambilan sampel menggunakan purposive sampling. Pengambilan sampel dari populasi 
dilakukan dengan memperhatikan homogenitas populasi tersebut, sehingga ditetapkan kelas VIIC sebagai sampel penelitian. Adapun teknik atau metode pengambilan data yang digunakan dalam penelitian ini adalah berupa angket. Angket merupakan daftar pernyataan secara tertulis yang diberikan kepada subyek penelitian untuk dijawab. Angket dalam penelitian ini digunakan untuk mengetahui keefektifan media pembelajaran daring dan motivasi belajar siswa, diberikan sebelum dan setelah perlakuan. Instrumen yang dipakai dalam penelitian ini adalah skala efektifitas penggunaan media pembelajaran online dan motivasi belajar siswa. Instrumen angket digunakan untuk memperoleh respon siswa terhadap pembelajaran menggunakan media pembelajaran online pada mata pelajaran IPA.

Angket dalam penelitian adalah berupa daftar pernyataan tertulis tipe pilihan force choice (pilihan paksa) dengan model skala Likert yang mengharuskan responden/siswa untuk menjawab suatu pernyataan dengan jawaban SS (sangat setuju), S (setuju), TS (tidak setuju), dan STS (sangat tidak setuju), dengan kisi-kisi sebagaimana yang terdapat pada Tabel 1. Adapun kriteria penskoran dijabarkan pada Tabel 2.

Tabel 1. Kisi-kisi Angket Penggunaan E-Learning Madrasah

\begin{tabular}{|c|c|c|c|c|}
\hline \multirow{2}{*}{ No. } & \multirow{2}{*}{ Pernyataan } & \multicolumn{3}{|c|}{ Jawaban } \\
\hline & & SS & S TS & STS \\
\hline 1 & Platform E-Learning madrasah mudah saya gunakan & & & \\
\hline 2 & $\begin{array}{l}\text { Dalam menggunakan Media E-Learning madrasah sering terkendala } \\
\text { kuota internet }\end{array}$ & & & \\
\hline 3 & $\begin{array}{l}\text { Media E-Learning madrasah mempermudah saya sebagai siswa } \\
\text { dalam mengerjakan tugas. }\end{array}$ & & & \\
\hline 4 & $\begin{array}{l}\text { 1 madrasah dalam pembelajaran Daring kurang memotivasi saya } \\
\text { dalam belajar }\end{array}$ & & & \\
\hline 5 & Dalam menggunakan E-Learning madrasah sering terkendala sinyal & & & \\
\hline 6 & Dengan E-Learning Madrasah mengerjakan tugas lebih cepat selesai & & & \\
\hline 7 & $\begin{array}{l}\text { Dengan menggunakan E-Learning madrasah, Saya sebagai siswa } \\
\text { dapat mengerjakan tugas dimanapun }\end{array}$ & & & \\
\hline 8 & $\begin{array}{l}\text { Pembelajaran Daring menggunakan E-Learning madrasah lebih } \\
\text { menarik dibandingkan pembelajaran tatap muka di sekolah }\end{array}$ & & & \\
\hline 9 & $\begin{array}{l}\text { Pembelajaran Tatap muka tidak perlu, karena pembelajaran } \\
\text { menggunakan E-Learning madrasah sudah cukup }\end{array}$ & & & \\
\hline 10 & $\begin{array}{l}\text { Menggunakan E-Learning madrasah bias membuat saya menguasai } \\
\text { materi pembelajaran IPA lebih mudah }\end{array}$ & & & \\
\hline 11 & $\begin{array}{l}\text { Walaupun Tidak ke sekolah saya masih bias belajar dengan } \\
\text { menggunakan E-Learning Madrasah }\end{array}$ & & & \\
\hline 12 & $\begin{array}{l}\text { Belajar menggunakan E-Learning Madrasah membuat saya bias } \\
\text { bergaul dengan teman seusia saya }\end{array}$ & & & \\
\hline 13 & $\begin{array}{l}\text { Penggunaan E-Learning madrasah lebih memotivasi saya dalam } \\
\text { belajar }\end{array}$ & & & \\
\hline 14 & $\begin{array}{l}\text { Penggunaan E-Learning madrasah membuat saya lebih terampil } \\
\text { menggunakan sarana teknologi dan informasi }\end{array}$ & & & \\
\hline 15 & $\begin{array}{l}\text { Penggunaan E-Learning madrasah mengembangkan kreativitas saya } \\
\text { dalam belajar }\end{array}$ & & & \\
\hline 16 & Dengan E-Learning Madrasah membuat saya sulit dalam belajar & & & \\
\hline 17 & $\begin{array}{l}\text { Hasil Belajar saya menggunakan E-Learning madrasah menjadi } \\
\text { lebih baik dan meningkat. }\end{array}$ & & & \\
\hline 18 & Saya bias mengetahui hasil belajar dengan menggunakan $E$ - & & & \\
\hline
\end{tabular}




\begin{tabular}{|c|c|c|c|c|}
\hline \multirow{2}{*}{ No. } & \multirow{2}{*}{ Pernyataan } & \multicolumn{3}{|c|}{ Jawaban } \\
\hline & & SS & S $\quad$ TS & STS \\
\hline & Learning madrasah & & & \\
\hline 19 & $\begin{array}{l}\text { Menggunakan E-Learning madrasah membutuhkan biaya yang } \\
\text { mahal }\end{array}$ & & & \\
\hline 20 & $\begin{array}{l}\text { E-Learning madrasah membuat saya sulit mengajukan pertanyaan } \\
\text { bila ada yang kurang dimengerti }\end{array}$ & & & \\
\hline 21 & $\begin{array}{l}\text { Fitur-Fitur yang terdapat dalam E-Learning madrasah mudah saya } \\
\text { gunakan }\end{array}$ & & & \\
\hline 22 & $\begin{array}{l}\text { Dengan menggunakan media E-Learning madrasah membuat saya } \\
\text { lebih antusias dalam belajar karena saya bias belajar dimanapun dan } \\
\text { kapanpun }\end{array}$ & & & \\
\hline 23 & $\begin{array}{l}\text { Dalam proses pembelajaran saya dapat menyelesaikan soal-soal/Quiz } \\
\text { yang diberikan oleh guru untuk dikerjakan secara mandiri }\end{array}$ & & & \\
\hline 24 & $\begin{array}{l}\text { Pembelajaran dengan materi Organisasi kehidupan ini dapat } \\
\text { meningkatkan motivasi saya dan keterampilan kreativitas saya }\end{array}$ & & & \\
\hline 25 & $\begin{array}{l}\text { Saya tidak senang membantu teman saya yang kesulitan dalam } \\
\text { mengerjakan soal dalam proses pembelajaran menggunakan E- } \\
\text { Learning madrasah }\end{array}$ & & & \\
\hline 26 & $\begin{array}{l}\text { Dengan menggunakan E-Learning madrasah dalam pembelajaran } \\
\text { daring saya dapat melakukan absensi secara otomatis }\end{array}$ & & & \\
\hline 27 & $\begin{array}{l}\text { Pembelajaran daring menggunakan E-Learning madrasah saya bias } \\
\text { langsung melihat nilai tugas saya }\end{array}$ & & & \\
\hline 28 & $\begin{array}{l}\text { Saya tidak bias menggunakan E-Learning madrasah dikarenakan } \\
\text { password yang saya masukan untuk log in selalu salah }\end{array}$ & & & \\
\hline 29 & $\begin{array}{l}\text { Pembelajaran IPA menggunakan E-Learning madrasah sangat } \\
\text { menarik karena bahan ajar yang disediakan guru seperti materi, } \\
\text { video pembelajaran bias langsung diunduh dan saya bias langsung } \\
\text { belajar materi tersebut }\end{array}$ & & & \\
\hline 30 & $\begin{array}{l}\text { Dengan E-Learning madrasah tetap membuat saya bias } \\
\text { berkomunikasi dengan teman-teman yang lain dalam belajar, diskusi } \\
\text { dan tanya jawab materi walaupun berada di tempat yang berbeda }\end{array}$ & & & \\
\hline
\end{tabular}

Tabel 2. Kriteria Skor Angket berdasarkan Skala Likert

\begin{tabular}{lclc}
\multicolumn{1}{c}{ Pernyataan Positif } & \multicolumn{1}{c}{ Pernyataan Negatif } \\
\hline \multicolumn{1}{c}{ Pernyataan } & Skor & \multicolumn{1}{c}{ Pernyataan } & Skor \\
Sangat Setuju (SS) & 4 & Sangat Setuju (SS) & 1 \\
Setuju (S) & 3 & Setuju (S) & 2 \\
Tidak Setuju (TS) & 2 & Tidak Setuju (TS) & 3 \\
Sangat Tidak Setuju (STS) & 1 & Sangat Tidak Setuju (STS) & 4 \\
\hline
\end{tabular}

\section{HASIL DAN PEMBAHASAN}

\section{Implementasi Pembelajaran Berbasis E-Learning Madrasah}

E-Learning madrasah adalah sebuah aplikasi gratis produk madrasah yang ditujukan untuk menunjang proses pembelajaran di sekolah-sekolah yang berada dibawah naungan kementerian agama seperti Madrasah mulai dari MI, MTs dan MA. Agar lebih terstruktur, menarik dan interaktif (Gambar 1). E-Learning madrasah memiliki enam role akses di antaranya:

1. operator madrasah;

2. guru mata pelajaran;

3. guru bimbingan dan konseling;

4. wali kelas; 
5. siswa; dan

6. kepala madrasah dan jajarannya.

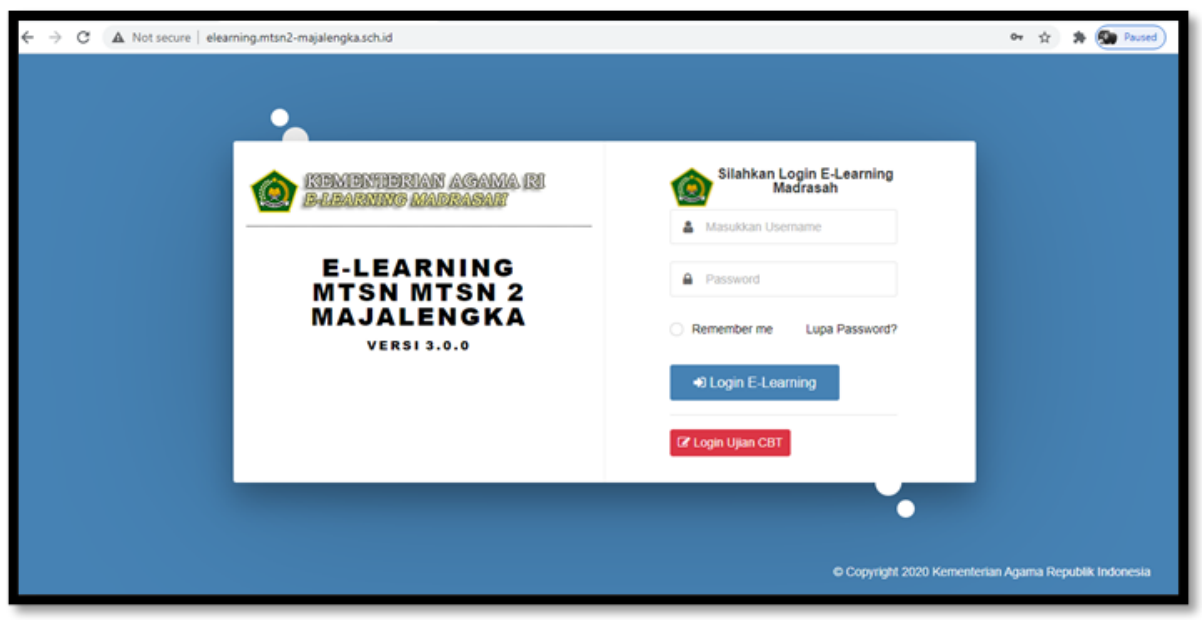

Gambar 1. Tampilan Halam Depan Aplikasi E-Learning Madrasah

Madrasah terus berinovasi dalam bidang teknologi dan informasi, yakni melalui pembelajaran berbasis daring atau E-Learning madrasah. Dalam E-Learning madrasah, peserta didik mendapatkan berbagai fitur yang mampu memudahkan mereka dalam mendapatkan informasi serta pembelajaran dengan cepat. Tidak hanya peserta didik, ada lima user/pengguna yang dapat mengakses E-Learning madrasah yaitu Operator Madrasah, guru mata pelajaran, guru bimbingan konseling, wali kelas dan kepala madrasah. Masing-masing memiliki username sendiri untuk dapat masuk dan log-in kedalam aplikasi E-Learning madrasah, kapanpun dan dimanapun.

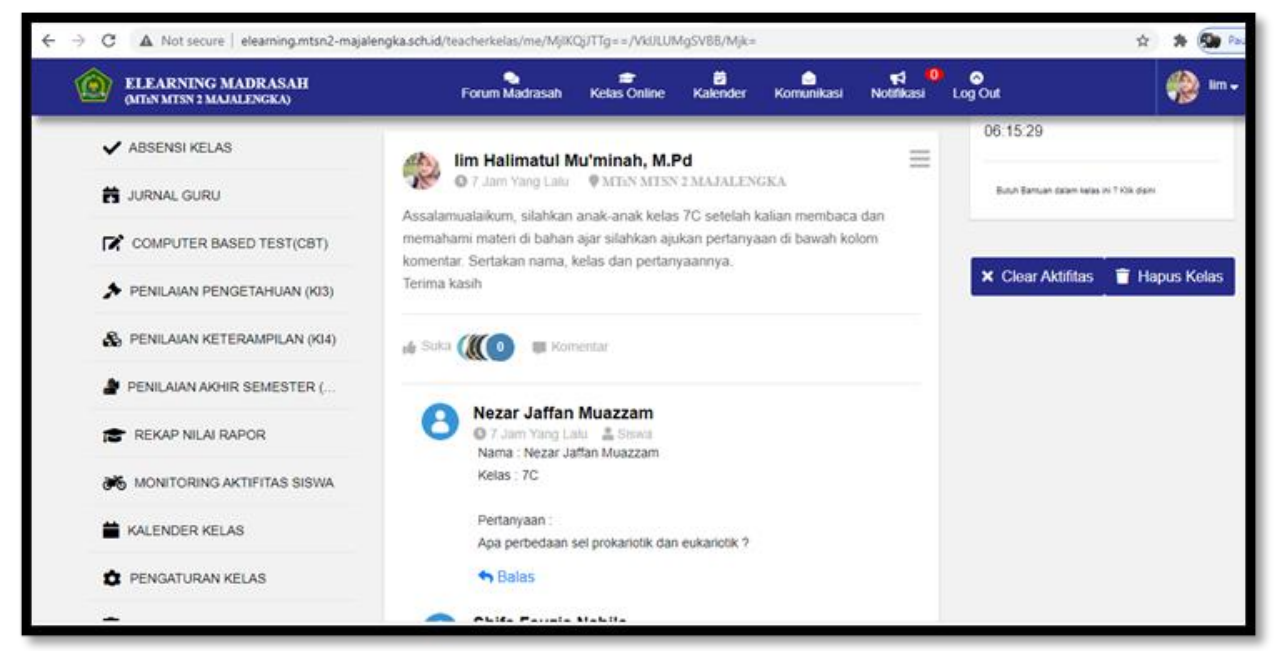

Gambar 2. Fitur-Fitur E-Learning Madrasah

Beberapa fitur dalam E-Learning tersebut, yaitu kelas daring berisi konten mulai dari awal proses pembelajaran, pembuatan standar kompetensi, rencana pelaksanaan pembelajaran (RPP), materi pembelajaran, jurnal guru, pengolahan penilaian harian, Computer Based Test (CBT) hingga pengolahan nilai rapor (Gambar 2). Kemudian, kedua guru berbagi. Fitur guru berbagi merupakan platform yang akan menampung kreatifitas guru madrasah untuk saling berbagi 
informasi apapun yang bermanfaat. Guru hanya tinggal mengunggah informasi tersebut dalam kolom dengan mudah. Di samping itu, siapapun dapat melihat dan berkomentar dan memberi masukan, bahkan menyukai unggahan tersebut. Selanjutnya Forum Komunitas Madrasah, peserta didik dan guru dapat dengan mudah berbagi ide dan membuka forum diskusi karena di dalam fitur ini terdapat media sosial untuk saling berkomunikasi antara guru dan peserta didik. User juga dapat saling berkomentar dan berbagi ide atau gagasan dalam fitur.

E-Learning madrasah merupakan sebuah aplikasi yang dibuat senyaman mungkin bagi para penggunanya agar mampu menarik semangat belajar dengan mudah, cepat di manapun dan kapanpun disituasi pandemi Covid-19 ini. Untuk dapat mengunduh aplikasi E-Learning madrasah, user harus terlebih dahulu melakukan log in sebagai operator madrasah (operator dapat mengunduh pada link ( https://elearning.kemenag.go.id/)

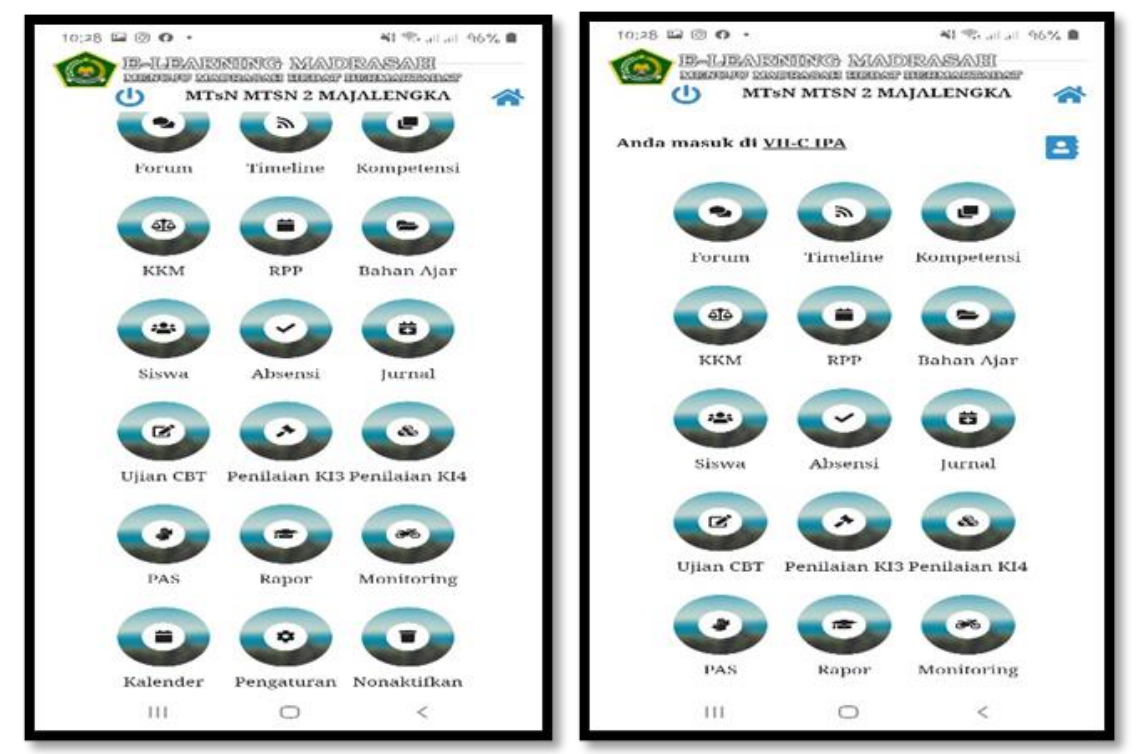

Gambar 3. Fitur-Fitur E-Learning Madrasah Pada Tampilan Layar Handphone

Bagi peserta didik tampilan layar fitur-fitur dalam E-Learning madrasah seperti halnya terlihat pada Gambar 3. Fitur-fitur tersebut memudahkan bagi peserta didik dalam proses pembelajaran secara daring. Seperti halnya pada fitur absensi, baik guru maupun peserta didik dapat dengan sangat mudah melakukan absensi pada fitur tersebut secara otomatis. Selain itu ada beberapa fitur ujian CBT, PAS, kemudian bahan ajar dan sebagainya semuanya dapat diakses oleh pengguna baik guru maupun peserta didik. 


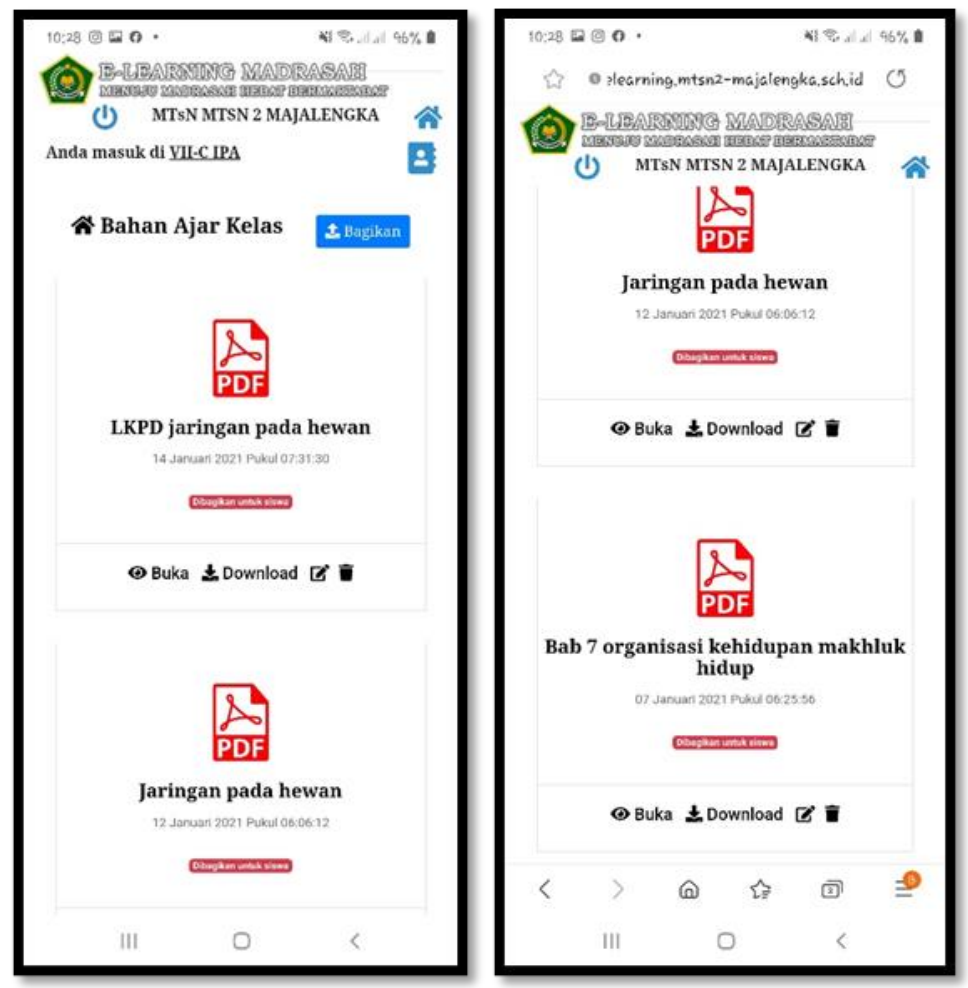

Gambar 4. Fitur Bahan Ajar/Modul Materi Pelajaran

Berdasarkan Gambar 4, merupakan fitur bahan ajar/modul materi pelajaran yang diunggah oleh guru yang kemudian dibagikan pada fitur bahan ajar. Kemudian peserta didik dapat dengan cepat dan mudah mengakses dan mengunduh file-file materi tersebut. File yang dapat diunggah oleh guru dapat berupa teks, Word, pdf, dan video pembelajaran. Setelah guru mengunggah file materi dan kemudian membagikannya, peserta didik dapat melakukan proses diskusi dengan mengajukan beberapa pertanyaan di kolom komentar yang sudah tersedia pada aplikasi E-Learning madrasah seperti halnya akan dijelaskan pada Gambar 5 berikut.

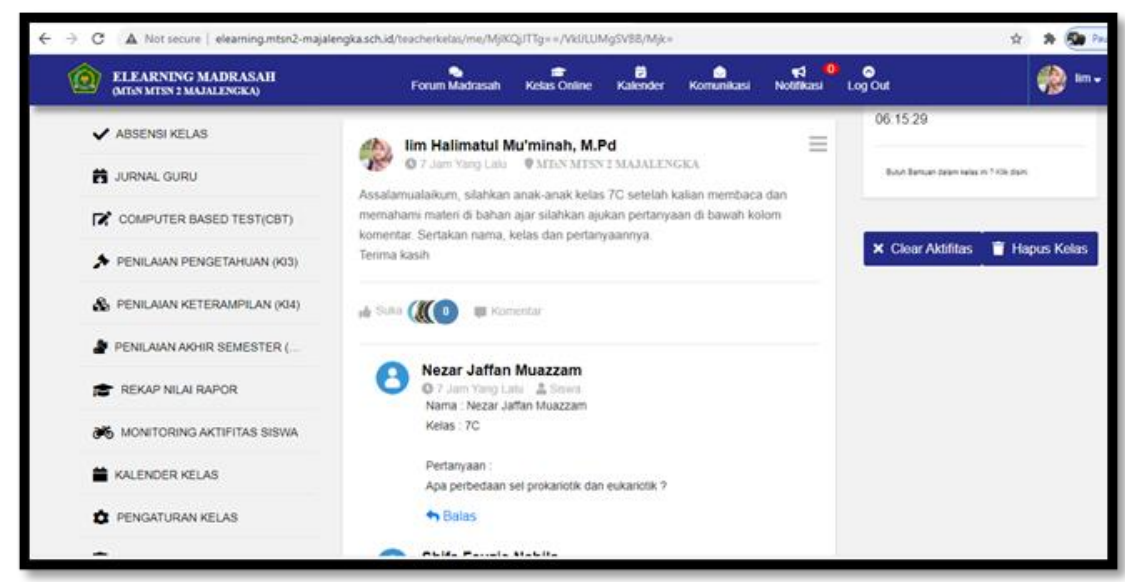

Gambar 5. Aktivitas Pembelajaran Guru Dan Peserta Didik 
Guru memberikan informasi kepada peserta didik terkait materi/modul bahan ajar yang telah disampaikan melalui fitur bahan ajar. Guru menginformasikannya dengan menuliskan informasi di kolom timeline, yang nantinya informasi tersebut akan terlihat dan dibaca oleh seluruh peserta didik pada timeline masing-masing peserta didik.

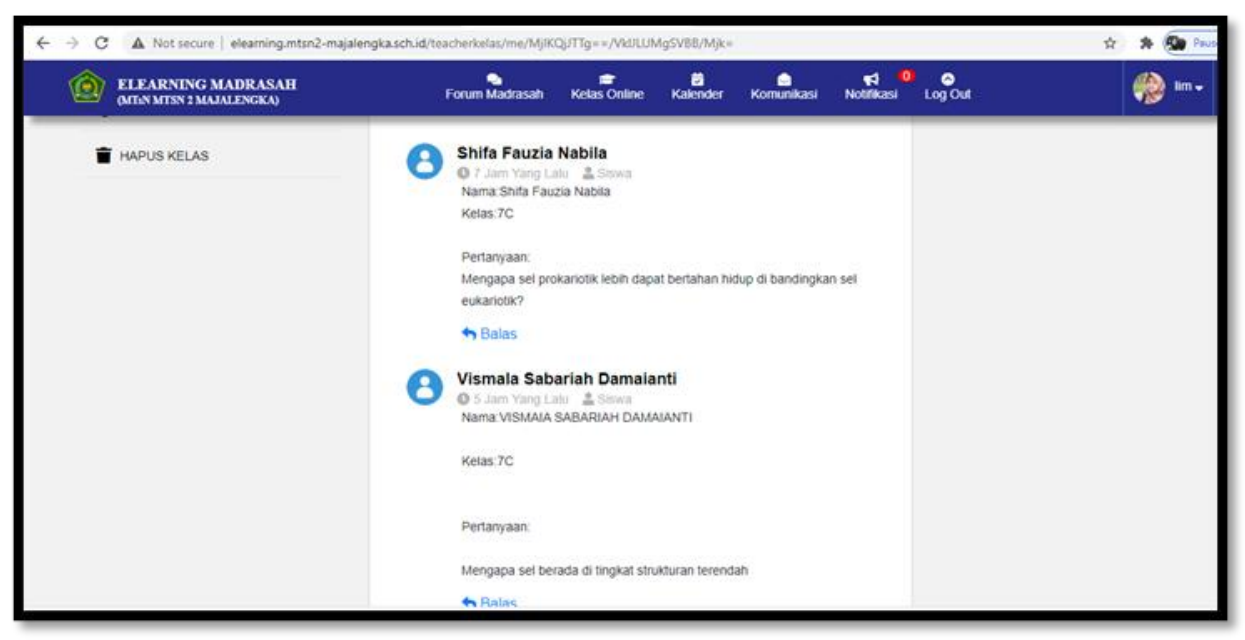

Gambar 6. Diskusi Pertanyaan Peserta Didik

Peserta didik mengajukan beberapa pertanyaan terkait pemahaman peserta didik pada materi yang disampaikan oleh guru. Di sini peserta didik dapat berdiskusi melakukan interaksi antara guru dan peserta didik maupun antar peserta didik (Gambar 6).

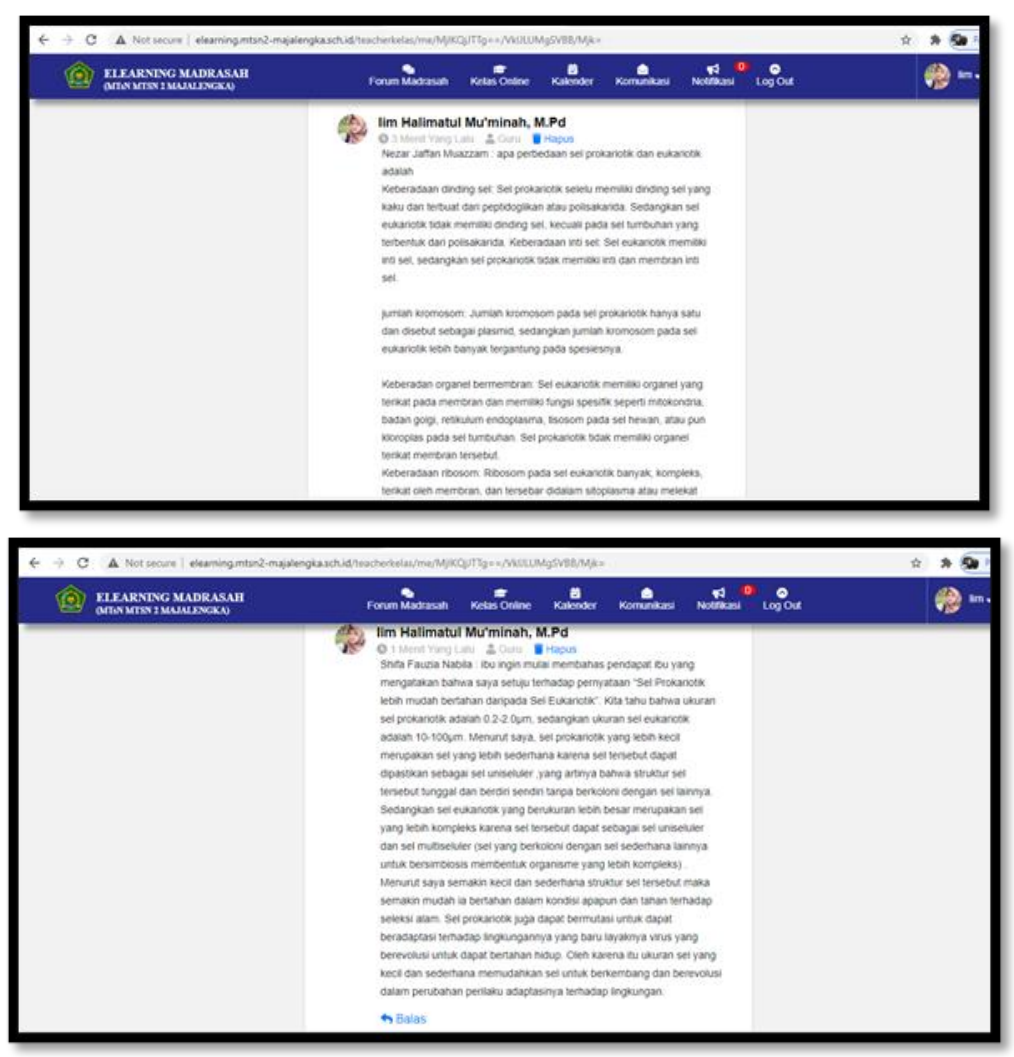

Gambar 7. Aktivitas Pembahasan Materi Oleh Guru 
Berdasarkan Gambar 7, merupakan aktivitas yang dilakukan oleh guru dalam menjawab dan membahas seluruh pertanyaan yang diampaikan oleh para peserta didik kepada guru. Guru dapat menuliskannya pada kolom komentar berikutnya terkait pembahasan materi pelajaran, begitu seterusnya sampai dengan jam pelajaran selesai dan peserta didik merasa puas terkait diskusinya.

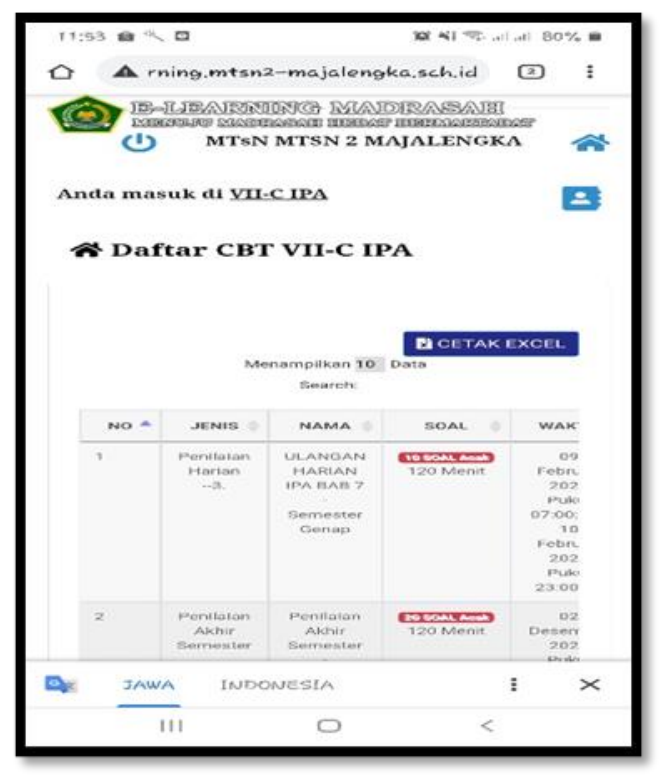

Gambar 8. Evaluasi Penilaian Harian Dan Ujian

Berdasarkan pada Gambar 8 diatas dapat dijelaskan terkait fitur ujian CBT, pada fitur ini guru mengunggah soal ulangan harian maupun ujian pada fitur ujian CBT. Dengan terlebih dahulu mengatur waktu dan hari pengerjaannya. Pada waktu yang telah ditentukan siswa dapat melaksanakan ulangan harian dan ujian pada fitur ujian CBT dan menyelesaikannya sesuai waktu yang sudah diatur oleh guru. Setelah siswa selesai mengerjakan soal ulangan harian dan ujian, guru dapat secara otomatis memonitoring pelaksanaan ujian, mengecek kehadiran siswa yang melaksanakan ujian dan secara otomatis melakukan evaluasi penilaian yang mana nilai secara otomatis akan muncul pada fitur CBT ini.

\section{Hasil Pengolahan Data Penelitian}

Setelah dilakukan pengolahan data dari jawaban para responden yakni peserta didik pada kelas yang dijadikan sampel, maka didapatkan skor rata-rata sebagaimana Tabel 3 berikut:

Tabel 3. Nilai Rata-Rata Pretest Dan Posttest Pembelajaran Daring Menggunakan E-Learning Madrasah

\begin{tabular}{lc}
\multicolumn{1}{c}{ Kategori } & Perolehan Skor \\
\hline Skor Rata-rata Pretest & 77,07 \\
Skor Rata-rata Posttest & 87,7 \\
\hline
\end{tabular}


Peningkatan pembelajaran berbasis E-Learning Madrasah pada mata pelajaran IPA diperoleh selisih skor pretest dan posttest selama pembelajaran. Skor maksimal siswa adalah 100 . Berdasarkan Tabel 3 dapat diketahui bahwa terjadi peningkatan pembelajaran berbasis $E$ Learning madrasah pada kelas tersebut. Skor rata-rata pretest sebesar 77,07. Setelah pembelajaran berbasis E-Learning madrasah pada mata pelajaran IPA skor rata-rata posstest siswa menjadi 87,7. Dengan demikian, dapat dijelaskan bahwa pada kelas tersebut pembelajaran berbasis E-Learning madrasah posttest lebih baik dari pretest dan menunjukkan hasil cukup tinggi. Maka pembelajaran berbasis E-Learning madrasah ini sudah berhasil dan dapat meningkatkan hasil belajar IPA pada kelas tersebut.

Tabel 4. Hasil Uji Data N-Gain Pembelajaran Daring Berbasis E-Learning Madrasah

\begin{tabular}{ccccc}
\hline Kelas Sampel & Rata-rata Skor Pretest & Rata-rata skor posttest & N-Gain & Kriteria \\
\hline VII-C & 77,07 & 87,7 & 0,48 & Sedang \\
\hline
\end{tabular}

Tabel 4 menunjukkan skor N-gain sebesar 0,48. Secara keseluruhan berdasarkan kategori menurut (Meltzer, 2002) maka kelas sampel tersebut peningkatan pembelajaran berbasis $E$ Learningnya berada pada kategori sedang, artinya seluruh siswa sudah mampu menguasai pembelajaran berbasis E-Learning madrasah.

Berdasarkan pada tabel 4 menunjukkan selisih peningkatan motivasi belajar siswa pada mata pelajaran IPA. Berdasarkan tabel diatas dapat dijelaskan bahwa nila rata-rata pretest motivasi belajar siswa di kelas sampel ini sebesar 77,43 dan setelah pembelajaran berbasis $E$ Learning madrasah mengalami peningkatan posttest sebesar 87,70. Dengan demikian dapat disimpulkan bahwa pembelajaran daring berbasis E-Learning madrasah dapat meningkatkan motivasi belajar siswa kelas VII-C. Berdasarkan data tersebut, menunjukkan skor N-gain sebesar 0,48. Secara keseluruhan, berdasarkan kategori menurut Meltzer (2002) maka peningkatan pembelajaran berbasis E-Learning-nya berada pada kategori sedang, artinya pembelajaran berbasis E-Learning madrasah sudah mampu meningkatkan motivasi belajar seluruh siswa kelas VII-C.

E-Learning madrasah pada dasarnya memiliki operasionalisasi yang hampir sama dengan LMS lainnya, yang merupakan "wadah" sebagaimana kelas luring dilaksanakan. Oleh karena itu, penggunaan LMS harus sebisa mungkin untuk dapat mempermudah siswa dalam melakukan proses pembelajaran. Hasil yang didapatkan dari penelitian ini sesuai dengan yang diperoleh Ratnawati \& Sulisworo (2021), bahwa penggunaan LMS Google Classroom mampu mempermudah siswa pada masa pembelajaran daring, sehingga efektif digunakan pada materi fluida tingkat SMA. Kemudahan tersebut disebabkan berbagai fasilitas yang terdapat pada Google Classroom yang mampu mendukung pembelajaran daring, seperti kemudahan penyimpanan 
dokumen materi maupun tugas, pengingat tugas yang datang berikut dengan deadline waktu pengumpulan, serta fasilitas pengumuman yang diberikan oleh pendidik secara cepat (real time).

Peningkatan motivasi siswa pada penelitian ini yang berada pada kategori sedang pada dasarnya merupakan bentuk adaptasi siswa pada proses pembelajaran daring yang berbeda dari biasanya yang dilakukan secara luring. Penyesuaian pengalaman yang peserta didik miliki pada pembelajaran daring belum dikategorikan maksimal karena sebelumnya peserta didik belum banyak mengalami atau bahkan tidak pernah mengalami pembelajaran daring sebelumnya. Hal ini sesuai dengan hasil penelitian Abdelmola et al., (2021) bahwa persepsi positif dari responden (dalam hal ini adalah peserta didik) terhadap pembelajaran daring berikut dengan segala komponen di dalamnya (termasuk LMS) adalah mungkin karena pengalaman pada peserta didik sebelumnya yang pernah melakukan aktivitas pembelajaran daring. Oleh karena itu, dapat diasumsikan bahwa peningkatan motivasi siswa dalam kegiatan pembelajaran daring akan meningkat seiring dengan pengalaman peserta didik melaksanakan pembelajaran daring.

\section{SIMPULAN}

Berdasarkan data rata-rata skor pretest dan posttest motivasi pada sampel dan N-Gain pada motivasi belajar siswa dapat disimpulkan bahwa tingkat efektifitas penggunaan pembelajaran daring berbasis E-leaning madrasah pada sampel dapat dikategorikan efektif dan mengalami peningkatan motivasi yang dikategorikan sedang. Dengan demikian, penggunaan $E$ Learning madrasah dapat meningkatkan motivasi belajar siswa selama masa pandemi Covid-19 pada mata pelajaran IPA.

\section{UCAPAN TERIMA KASIH}

Penelitian ini bias terlaksana atas dukungan dari berbagai pihak. Pada kesempatan ini penulis mengucapkan terima kasih kepada Pusat Penelitian dan Pengabdian Kepada Masyarakat (P3M) Universitas Majalengka sebagai lembaga yang telah memberikan dana penelitian; MTs Negeri 2 Majalengka yang telah memfasilitasi tempat penelitian.

\section{REFERENSI}

Abdelmola, A. O., Makeen, A., Hanafi, H. M., \& Ageeli, E. (2021). E-Learning during COVID19 Pandemic, Faculty Perceptions, Challenges, and Recommendations. MedEdPublish, 10(1), 1-15. https://doi.org/10.15694/mep.2021.000112.1

Aji, R. H. S. (2020). Dampak Covid-19 pada Pendidikan di Indonesia: Sekolah, Keterampilan, dan Proses Pembelajaran. SALAM: Jurnal Sosial Dan Budaya Syar-I, 7(5), 395-402. https://doi.org/10.15408/sjsbs.v7i5.15314

Clark, A. E., Nong, H., Zhu, H., \& Zhu, R. (2021). Compensating for academic loss: Online learning and student performance during the COVID-19 pandemic. China Economic Review, 68, 101629. https://doi.org/10.1016/j.chieco.2021.101629 
Gohiya, P., \& Gohiya, A. (2020). E -learning during Covid 19 Pandemic. 4-9. https://doi.org/10.21203/rs.3.rs-29575/v1

Hartanto, W. (2016). Penggunaan E-Learning sebagai Media Pembelajaran. Jurnal Pendidikan Ekonomi, 10(1), 1-18.

Ibrahim, D., S., \& Suardiman, S., P. (2014). Pengaruh Penggunaan E-Learning Terhadap Motivasi Dan Prestasi Belajar Matematika Siswa Sd Negeri Tahunan Yogyakarta. Jurnal Prima Edukasia, 2(1), 66-79. https://doi.org/10.21831/jpe.v2i1.2645

Jogezai, N. A., Baloch, F. A., Jaffar, M., Shah, T., Khilji, G. K., \& Bashir, S. (2021). Teachers' attitudes towards social media (SM) use in online learning amid the COVID-19 pandemic: the effects of SM use by teachers and religious scholars during physical distancing. Heliyon, 7(4), e06781. https://doi.org/10.1016/j.heliyon.2021.e06781

Januarisman, W., \& Ghufron, A. (2016). Pengembangan Media Pembelajaran Berbasis Web Mata Pelajaran Ilmu Pengetahuan Alam Untuk Siswa Kelas VII. Jurnal Inovasi Teknologi Pendidikan, 3(2). 166-182. https://doi.org/10.21831/jitp.v3i2.8019

Meltzer, D., E. (2002). The relationship between mathematics preparation and conceptual learning gains in physics: A possible "hidden variable" in diagnostic pretest scores. American Journal of Physcics, 70(12). 1259-1268. https://doi.org/10.1119/1.1514215

Mustakim. (2020). Efektivitas Pembelajaran Daring Menggunakan Media Online Selama Pandemi Covid-19 Pada Mata Pelajaran Matematika. Al asma: Journal of Islamic Education, 2(1). 1-12. https://doi.org/10.24252/asma.v2i1.13646

Nugraha, S., A., Sudiatmi, T., Suswandari, M. (2020). Studi Pengaruh Daring Learning terhadap Hasil Belajar Matematika Kelas IV. JIP: Jurnal Inovasi Penelitian, 1(3). 265-276.

Putria, H., Maula, L. H., \& Uswatun, D. A. (2020). Analisis Proses Pembelajaran dalam Jaringan (DARING) Masa Pandemi Covid- 19 Pada Guru Sekolah Dasar. Jurnal Basicedu, 4(4), 861-870. https://doi.org/10.31004/basicedu.v4i4.460

Rahmi, R. (2020). Inovasi Pembelajaran Di Masa Pandemi Covid-19. AL-TARBIYAH: Jurnal Pendidikan (The Educational Journal), 30(2). https://doi.org/10.24235/ath.v30i2.6852

Ratnawati, H., \& Sulisworo, D. (2021). Efektivitas E-Learning Berbasis LMS Google Classroom dengan Strategi Discovery Learning Materi Fluida Statis SMA. Jurnal Penelitian Pendidikan Fisika, 6(2), 137-145. https://doi.org/10.36709/jipfi.v6i2.17162

Rosali, E. S. (2020). Aktivitas Pembelajaran Daring Pada Masa Pandemi Covid -19 Di. Geography Science Education Journal (GEOSEE), 1(1), 21-30. https://www.researchgate.net/publication/340917125_Kendala_Pelaksanaan_Pembelajara n_Jarak_Jauh_PJJ_dalam_Masa_Pandemi/stats

Sadikin, A., \& Hamidah, A. (2020). Pembelajaran Daring di Tengah Wabah Covid-19. Biodik, 6(2), 109-119. https://doi.org/10.22437/bio.v6i2.9759

Septiawan, F. (2020). Efektivitas Penggunaan Google Form dalam Pembelajaran Daring Pada Mata Pelajaran Pemeliharaan Mesin Sepeda Motor di SMK Negeri 1 Koba. Jurnal Pendidikan Teknik Mesin, 7(2). 129-135. https://doi.org/10.36706/jptm.v7i2.12276

Sethi, P. C., \& Behera, P. K. (2021). Effective online teaching learning during COVID-19 pandemic. Journal of Physics: Conference Series, 1797(1). https://doi.org/10.1088/17426596/1797/1/012068

Sharma, A., \& Singh, P. (2017). Learning Management System for Virtual Teaching and Learning. World Academics Journal of Engineering Science, 4(1), 5-7.

Zulkifli, N., \& Ferdiansyah, H. (2021). Efektifitas Media Pembelajaran Daring di masa Pandemi Covid-19. Jurnal Pendidikan, 5(1), 71-77. https://doi.org/10.33487/edumaspul.v5i1.1123 